\title{
Sporormiella as a tool for detecting the presence of large herbivores in the Neotropics
}

\author{
Marco Felipe Raczka ${ }^{1,3}$, Mark B. Bush ${ }^{1}$, Alexandra M. Folcik ${ }^{1}$ \& Crystal H. McMichael ${ }^{2}$ \\ ${ }^{1}$ Florida Institute of Technology, Biological Sciences, 150 W. University Blvd, Melbourne, Florida 32901, \\ United States. \\ ${ }^{2}$ University of Amsterdam, Palaeoecology \& Landscape Ecology, Institute for Biodiversity \& Ecosystem \\ Dynamics, Amsterdam, Netherlands. \\ ${ }^{3}$ Corresponding author: Marco FelipeRaczka, e-mail: mraczka2009@my.fit.edu
}

RACZKA, M.F., BUSH, M.B., FOLCIK, A.M., MCMICHAEL, C.H. Sporormiella as a tool for detecting the presence of large herbivores in the Neotropics. Biota Neotropica. 16(1): e20150090. http://dx. doi.org/10.1590/1676-0611-BN-2015-0090

\begin{abstract}
The reliability of using the abundance of Sporormiella spores as a proxy for the presence and abundance of megaherbivores was tested in southern Brazil. Mud-water interface samples from nine lakes, in which cattle-use was categorized as high, medium, or low, were assayed for Sporormiella representation. The sampling design allowed an analysis of both the influence of the number of animals using the shoreline and the distance of the sampling site from the nearest shoreline. Sporormiella was found to be a reliable proxy for the presence of large livestock. The concentration and abundance of spores declined from the edge of the lake toward the center, with the strongest response being in sites with high livestock use. Consistent with prior studies in temperate regions, we find that Sporormiella spores are a useful proxy to study the extinction of Pleistocene megafauna or the arrival of European livestock in Neotropical landscapes.

Keywords: Extinction, fossil pollen, lake sediment, livestock, Pleistocene Megafauna, Sporormiella spores.
\end{abstract}

RACZKA, M.F., BUSH, M.B., FOLCIK, A.M., MCMICHAEL, C.H. Sporormiella como ferramenta para detectar a presença de grandes herbívoros na região Neotropical. Biota Neotropica. 16(1): e20150090. http://dx.doi.org/10.1590/1676-0611-BN-2015-0090

\begin{abstract}
Resumo: A confiabilidade dos valores de Sporormiella como um proxy para estimar a presença e abundância de megaherbívoros foi testada na região sudeste do Brasil. Amostras superficiais de nove lagos, categorizados quanto a presença de gados em alto, médio e baixo uso do seu entorno foram coletadas para a análise de abundância de Sporormiella. O modelo amostral aplicado permitiu a interpretação tanto da influência do número de animais que usam a margem do lago quanto a distância da margem do lago sobre a quantidade de esporos encontrados. As análises indicam que esporos de Sporormiella é um excelente proxy para detectar a presença de grandes herbívoros. A concentração e abundância de esporos reduz em direção ao centro do lago, o que fica mais evidente em locais com alto uso do entorno do lago por esses animais. Consistente com estudos realizados em regiões temperadas, nós concluímos que o uso de Sporormiella se mostra de grande valia para entender a extinção da megafauna do Pleistoceno como também a introdução de animais nas paisagens neotropicais.

Palavras-chave: Extinção, pólen fóssil, sedimentos lacustres, pecuária, Megafauna Pleistocênica, Sporormiella.
\end{abstract}

\section{Introduction}

The Pleistocene megafauna were animals that exceeded 100 kilograms (Johnson 2002, Martin \& Steadman 1999), such as ground sloth, mastodon, and glyptodonts. In South America, the Late Pleistocene extinction resulted in the loss of 57 genera of megafauna (Barnosky \& Lindsey 2010, Martin \& Klein 1984, Martin \& Steadman 1999). With the arrival of Europeans, domesticated megafauna, such as cows, horses and oxen, were introduced to many areas. Both in pre-history and now, megafauna produce a wide range of effects on terrestrial ecosystems that can disturb and alter the functioning of the ecosystem (Ripple \& Van Valkenburgh 2010). Some of these effects are direct, for example removal and consumption of vegetation, while other effects are indirect, such as alterations of rates of nutrient cycling (Augustine \& McNaughton
1998, Doughty et al. 2013, Johnson 2009, MacFadden \& Shockey 1997, McNaughton 1985, Smith et al. 2010).

The extinction of megafauna at the end of the Pleistocene has intrigued researchers for decades (Gill 2014). Environmental change (Grayson \& Meltzer 2002, Macphee 1999) combined with human hunting pressure (Blitzkrieg) (Martin 1973, Miller et al. 1999) is the leading hypothesis to explain the extinction. For most of the 20th century, fossilized bones were the only evidence to assess the demise of these unique Quaternary animals (Webb et al. 1984). Fossils are scarce, and in most of the cases only provide descriptive interpretation (Borrero 2009). Because of these limitations, an additional proxy for megafauna is necessary that is common, tightly associated with megafaunal presence, and can be found in temporally intact paleoecological archives (Bakker et al. 2015). 


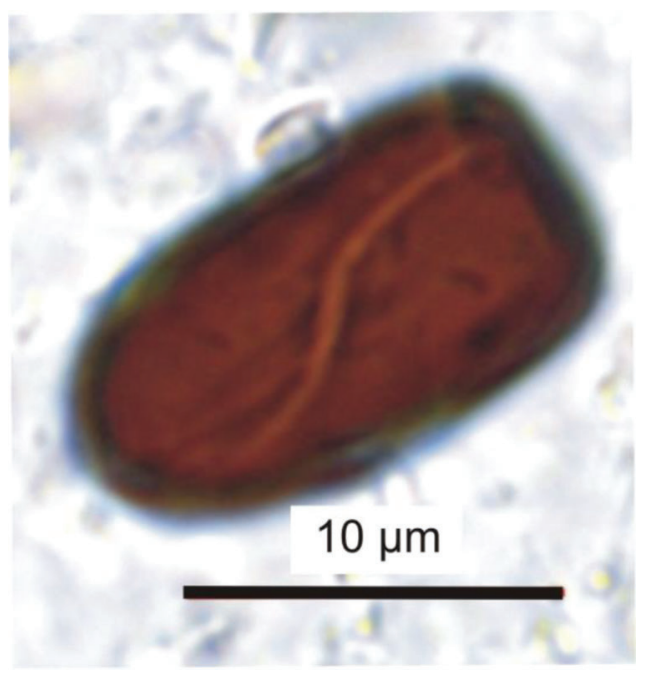

Figure 1. Photomicrograph of a single Sporormiella cell (terminal segment) showing the aperture in s-shape that facilitates the identification of the spore.

Figura 1. Fotomicrografia de uma célula única de Sporormiella (segmento terminal) mostrando a abertura em forma de 's' que facilita a identidicação do esporo.

Spores of Sporormiella (Figure 1), a genus of primarily coprophilous fungi, are now widely used to detect mega herbivore presence and even estimate their abundance in paleoecological reconstructions (Davis \& Shafer 2006, Gill et al. 2012, Gill et al. 2009, Robinson et al. 2005). Though pioneered in the Great Plains of the USA (Davis 1987, Davis et al. 1977), Sporormiella has been used to reconstruct the presence of Moas in New Zealand (Wood et al. 2011), Giant tortoises in the Galapagos (Froyd et al. 2013), Giant lemurs, elephant birds and the pygmy hippopotamus in Madagascar (Burney et al. 2003).

Despite the growing scientific literature regarding the role of Sporormiella in Quaternary sediments, very few studies have been conducted in modern settings to assess the reliability of the spores as a proxy for megafauna (Etienne et al. 2012, Gill et al. 2013, Raper \& Bush 2009). Modern megafauna, such as cows, are analogs of Pleistocene megafauna that can be used to calibrate Sporormiella signatures in paleoecological studies. According to Raper \& Bush (2009), Sporormiella can be a common element of lake sediments in localities with modern cattle presence, particularly samples collected near the shoreline. The dispersion of Sporormiella into lake sediments is likely affected by the abundance of animals in the region, transportation of the spores by physical agents after defecation, and physical characteristics of the lake basin. Higher concentrations of Sporormiella at the shoreline probably result from the relatively heavy spore structure that causes the fungus cell to sink rapidly. An exponential decline in spore concentration with increasing distance from shoreline was suggested by Raper \& Bush (2009) for the shallow flat-bottomed lakes of Florida. Parker \& Williams (2012) found that in dam and natural lakes in the US Great Plains, Midwestern USA, the decline from shoreline to the center was linear. A study of mountain lakes in the French Alps suggested that the Sporormiella concentrations were a function of flows that transported plumes of Sporormiella into deep water.

No study of Sporormiella occurrence has yet been undertaken in South American systems. The presence of a suite of mid-sized rodents and herbivores that are commonly found around lakes, e.g. capybara, agouti, paca, and deer could complicate the use of Sporormiella as a marker of Pleistocene megafauna. Here we aim to: (1) test the association between Sporormiella concentrations in modern sediments and the presence of introduced European animals, (2) Determine if the use of livestock has a significant impact on Sporormiella concentrations; and (3) test whether Sporormiella declines with distance from the shoreline.

\section{Material and Methods}

To understand the association between megafauna abundance and Sporormiella representation in lake sediment archives, we sampled nine lakes with different cattle use in the adjacent landscape: i) High cattle use ( $>40$ per day visiting the lake); ii) Medium cattle use ( $\sim 10$ per day visiting the lake), and iii) Low cattle use $(<5$ per day visiting the lake). We also examined whether the abundance of Sporormiella was related to distance from the lake shoreline (Raper \& Bush 2009).

\section{Experimental design}

To compare Sporormiella signatures along a gradient of cattle densities, we selected nine flat-bottomed lakes across southeastern Brazil (Table 1), in the São Paulo and Minas Gerais (Figure 2). The sampled lakes are situated in the southeastern region of Brazil in the cerrado (Goodland \& Pollard 1973), and in the Atlantic rain forest (Morellato \& Haddad 2000). Lakes ranged in size from 100 to $150 \mathrm{~m}$ in diameter and were classified according to the use by livestock. Due to limited

Table 1. Attributes and characteristics of each lake. Lakes with asterisk are also being analyzed for paleoecological reconstructions.

Tabela 1. Atributos e características de cada lago. Lagos marcados com asterísco também estão sendo analisados para estudos paleoecológcos.

\begin{tabular}{|c|c|c|c|c|c|}
\hline Lake Name & Elev. (m) & Lat./Long. & Depth (m) & \# Samples & Category \\
\hline Araça/MG & 806 & $19^{\circ} 31^{\prime} 48 \mathrm{~S} / 44^{\circ} 6 ’ 28 \mathrm{~W}$ & 1.8 & 20 & High \\
\hline Maria/SP & 760 & $23^{\circ} 6^{\prime} 41 \mathrm{~S} / 46^{\circ} 31^{\prime} 25 \mathrm{~W}$ & 2 & 8 & High \\
\hline Pedrinha/MG & 702 & $19^{\circ} 33^{\prime} 42 \mathrm{~S} / 44^{\circ} 7^{\prime} 21 \mathrm{~W}$ & 1.5 & 12 & High \\
\hline Guilto/MG & 720 & $19^{\circ} 28^{\prime} 48 \mathrm{~S} / 44^{\circ} 9^{\prime} 1 \mathrm{~W}$ & 2.4 & 20 & Medium \\
\hline Fora/MG & 700 & $19^{\circ} 26^{\prime} 48 \mathrm{~S} / 44^{\circ} 11 \mathrm{~W}$ & 2.6 & 20 & Medium \\
\hline Rocha/SP & 645 & $21^{\circ} 52^{\prime} 40 \mathrm{~S} / 47^{\circ} 5^{\prime} 19 \mathrm{~W}$ & 1.5 & 8 & Low \\
\hline Serra Negra/MG * & 1170 & $18^{\circ} 53^{\prime} 31 \mathrm{~S} / 46^{\circ} 49^{\prime} 29 \mathrm{~W}$ & 1.5 & 9 & Low \\
\hline Branca/SP * & 710 & $21^{\circ} 54^{\prime} 12 \mathrm{~S} / 47^{\circ} 1^{\prime} 46 \mathrm{~W}$ & 1.8 & 11 & Low \\
\hline Sumidouro/MG & 648 & $19^{\circ} 32^{\prime} 20 \mathrm{~S} / 43^{\circ} 56^{\prime} 32 \mathrm{~W}$ & 0.8 & 12 & Low \\
\hline
\end{tabular}



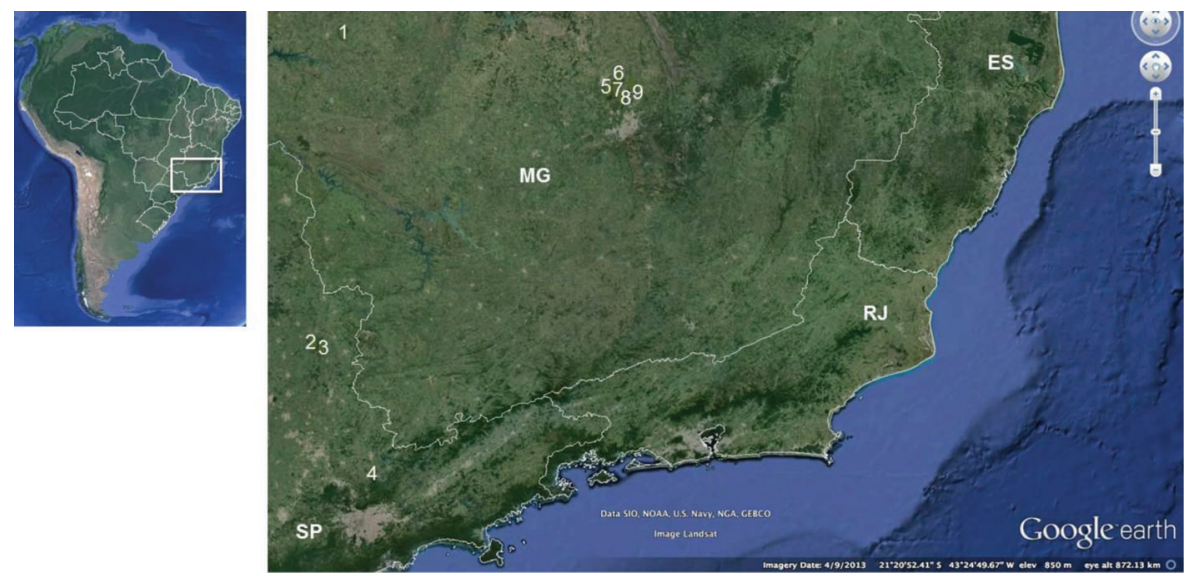

Figure 2. Image of the study area showing the lakes from which mud-water interface samples were collected. $1=$ Lake Serra Negra; $2=$ Lake Rocha; $3=$ Lake Branca; 4 = Lake Maria; 5 = Lake Guilto; 6 = Lake Fora; 7 = Lake Araçá; 8 = Lake Pedrinha; $9=$ Lake Sumidouro; SP = São Paulo; $\mathrm{MG}=$ Minas Gerais; RJ = Rio de Janeiro; ES = Espirito Santo.

Figura 2. Imagem da área de estudo com os lagos nos quais amostras superficiais foram coletadas. 1 = Lago Serra Negra; 2 = Lago do Rocha; 3 = Lagoa Branca; 4 = Lago Maria; 5 = Lago do Guilto; 6 = Lagoa de Fora; 7 = Lago Araça; 8 = Lago Pedrinha; 9 = Lagoa do Sumidouro; $\mathrm{SP}=$ São Paulo; $\mathrm{MG}=$ Minas Gerais; RJ = Rio de Janeiro; ES = Espírito Santo.

access to private properties, it was not possible to get an even number of lakes across all categories of lakes three high-use lakes, two medium-use lakes, and four low-use lakes.

Each lake was divided into concentric rings representing intervals of distance from the lake shoreline (Figure 3). The outermost ring represented $2.5 \mathrm{~m}$ from shoreline, the second interval was $15 \mathrm{~m}$ from the shoreline, then $35 \mathrm{~m}$, and the last one was $50 \mathrm{~m}$. The number of samples collected within each ring was proportional to the surface area of the ring. Thus, more samples were collected in the outermost ring than in the inner rings. Sample locations within each ring were randomly selected. It is important to observe that at Lake Maria, samples from 35 and 50 meters distances were unavailable due to a fence that prevented boat access to the center of the lake. All samples were obtained from the mudwater interface using an Ekman dredge sampler that was released

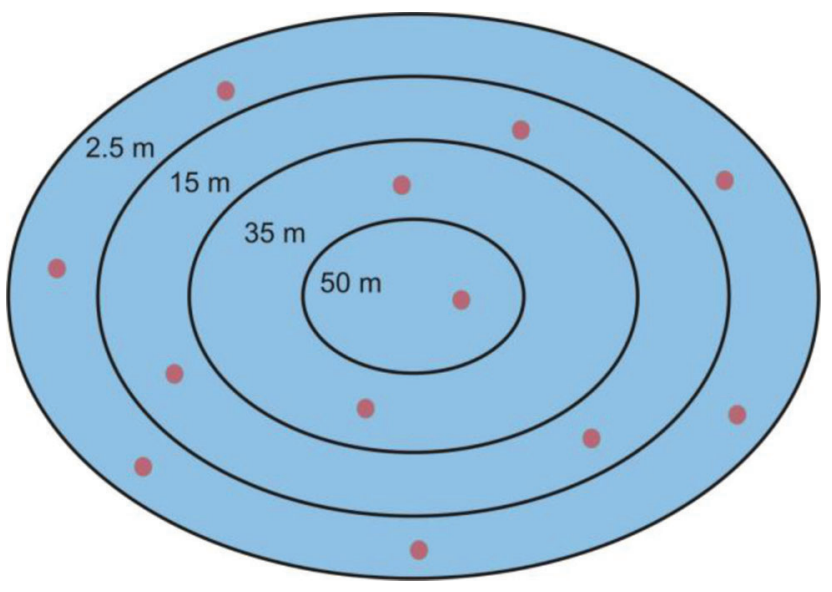

Figure 3. Sketch diagram of the sampling method used showing the concentric rings guiding sampling. Each ring represents a given distance from the lake shoreline. The number of samples from each ring was proportional to its surface area.

Figura 3. Diagrama esquemático do método de amostragem com os intervalos amostrais. Cada intervalo amostral representa a distância da margem do lago. O número de amostras em cada intervalo amostral foi proporcional à sua área de superfície. from an inflatable boat. A total of 120 samples were obtained summing data for all lakes.

\section{Subsampling}

From each sample collected, $1.0 \mathrm{~cm}^{3}$ of wet sediment was subsampled and processed following standard protocols for palynological analyses (Faegri \& Iversen 1989) and separated by density using sodium metatungstate to concentrate the palynomorphs. In each sample, a Lycopodium spike containing a known number of spores was added. This technique was used to determine spore and pollen concentrations (Stockmarr 1971). In each sample, 300 pollen grains were counted using a Zeiss Axioskop at magnifications of 630x and 1000x as this typified the sampling effort applied to paleoecological samples (Absy 1991, Colinvaux et al. 1997, Colinvaux et al. 1999, Colinvaux et al. 1996, Ledru et al. 1998, Ledru 1993). Sporormiella spores were identified by consulting photographs and through physical descriptions (Aptroot \& van Geel 2006, Davis \& Shafer 2006, van Geel et al. 2011).

\section{Statistical Analysis}

The spore abundances were compared across distance intervals (concentric rings), and between livestock densities. The data were analyzed using a generalized linear model (Gelman \& Hill 2007) from the package stats using the statistical program R (R Development Core Team 2015). Distance from the shoreline was the predictor to determine if the mean of the samples at each segment from each lake was significantly different from another. Also, we performed a Two Way ANOVA to analyze if a significant difference existed among lakes supporting high, medium or low livestock use.

\section{Results}

\section{Lakes}

Sporormiella spores were present in 97 out of the 120 samples analyzed. In lakes with high cattle use, spores abundance ranged 6.3 and $48.6 \%$ of the total pollen sum. At locations with medium 


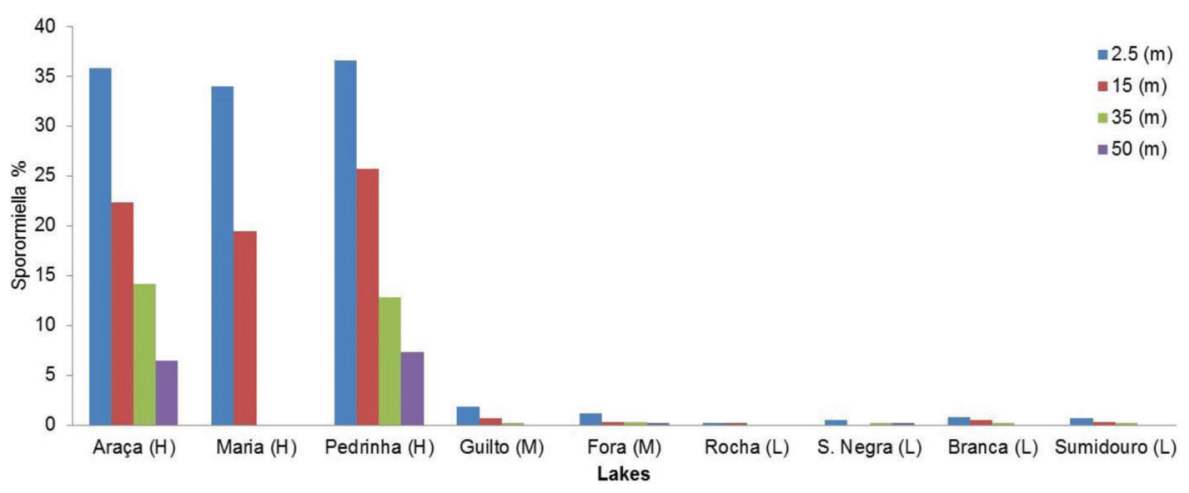

Figure 4. Percentage data for Sporormiella representation relative to the pollen sum. Each value represents an average for the given distances from the nearest shoreline. The letters after the names of the lakes denote the category of each lake: $\mathrm{H}=$ High cattle use; $\mathrm{M}=\mathrm{Medium}$ cattle use, and $\mathrm{L}=$ Low cattle use.

Figura 4. Dados de porcentagem de Sporormiella relativos à soma total de pólen. Cada valor representa a média da distância da margem do lago. As letras após o nome do lago indica a categoria de cada lago: $\mathrm{H}=$ Alto; $\mathrm{M}=$ Médio; $\mathrm{L}=$ Baixo.

Table 2. Two Way ANOVA for percentages data. Dependent Variable: Sporormiella . a. R Squared $=.994$ (Adjusted R Squared $=.991$ ). Tabela 2. Two Way ANOVA dos dados de porcentagem. Variável dependente: Sporormiella. a. R Squared $=.994$ (Adjusted R Squared $=.991$ ).

\begin{tabular}{lcrrr}
\hline Source & Type III Sum of Squares & df & Mean Square & F \\
\hline Corrected Model & $4297.941 \mathrm{a}$ & 11 & 390.722 & 348.304 \\
Intercept & 1430.452 & 1 & 1430.452 & 1275.159 \\
Category & 2542.458 & 2 & 1271.229 & 1133.222 \\
Distance & 452.214 & 3 & 150.738 & $<\mathbf{0 . 0 0 1}$ \\
Category * Distance & 761.889 & 6 & 126.981 & $<\mathbf{0 . 0 0 1}$ \\
Error & 24.679 & 22 & 1.122 & $<001$ \\
Total & 5788.643 & 34 & & $<\mathbf{0 . 0 0 1}$ \\
Corrected Total & 4322.621 & 33 & & \\
\hline
\end{tabular}

and low cattle use, the highest spore per sample found was $6.3 \%$ of total pollen sum.

Percentages of Sporormiella spores were significantly higher at locations with high cattle use in comparison with locations with medium and low cattle use ( $p<0.001$; Figure 4 ; Table 2$)$.

Concentrations of Sporormiella in lakes with high cattle use varied from 1203.9 to 6741.5 spores per $\mathrm{cm}^{3}$. Locations with medium and low cattle use had much lower concentrations of spores, with values ranging from 0 to 338.7 spores per $\mathrm{cm}^{3}$. In all cases, samples located at shoreline had concentrations of Sporormiella significantly higher than samples close to the center of the lake. The Two Way ANOVA for concentrations of Sporormiella per $\mathrm{cm}^{3}$ also showed that high cattle densities locations were significantly different from locations with medium and low cattle densities ( $p<0.001$; Figure 5; Table 3$)$.

\section{Distances}

The generalized linear model applied to the percentage and concentration data allowed us to identify the variance among distances within each lake category. Abundance of Sporormiella spores followed the same pattern for all lake categories. As the distance from the shoreline increased the abundance of spores decreased. At lakes with high cattle use (Figure $6 \mathrm{~A}$ and D), the percentage and concentration of Sporormiella were significantly different ( $p<0.001$; Tables 4 and 5) across all distances. Shoreline samples had values notably higher than all the other samples. There was an evident pattern showing the decrease of
Sporormiella abundance toward the center of the lake. In medium and low cattle use locations, the same pattern of decreasing abundance of Sporormiella toward the center of the lake was observed, however, in these two categories of lakes the maximum abundance of Sporormiella decreased to values less

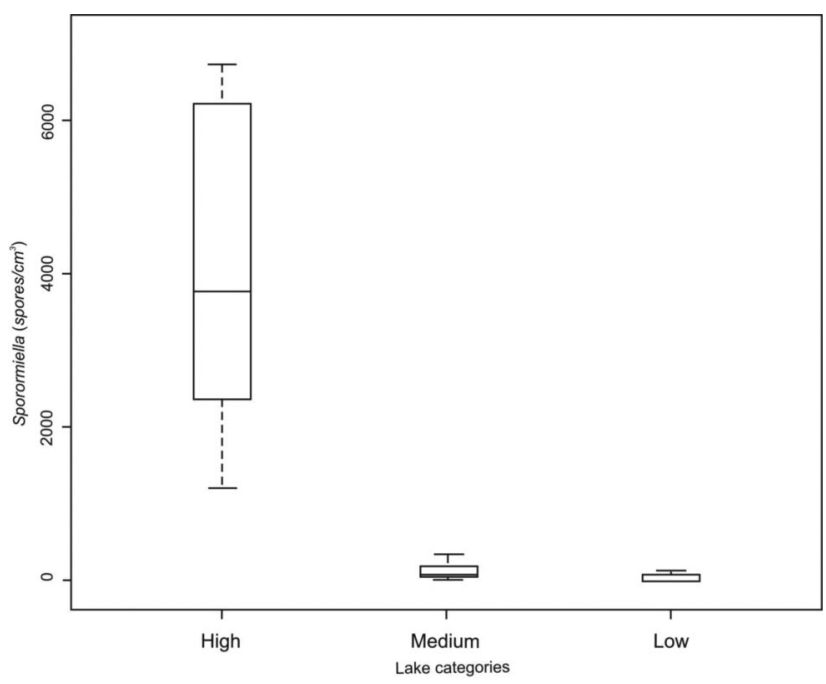

Figure 5. Average concentrations of Sporormiella across all distances for the three different use categories of lakes.

Figura 5. Média da concentração de Sporormiella de todas as distâncias para as três categorias de lagos. 
Testing Sporormiella as a proxy

Table 3. Two Way ANOVA for concentration data. Dependent Variable: Sporormiella concentration. a. R Squared $=.994$ (Adjusted R Squared $=.991$ ). Tabela 3. Two Way ANOVA dos dados de concentração. Variável dependente: Sporormiella. a. R Squared $=.994$ (Adjusted R Squared $=.991$ ).

\begin{tabular}{|c|c|c|c|c|c|}
\hline Source & Type III Sum of Squares & df & Mean Square & $\mathbf{F}$ & Sig. \\
\hline Corrected Model & $144.229 \mathrm{a}$ & 11 & 13.112 & 315.145 & $<0.001$ \\
\hline Intercept & 48.140 & 1 & 48.140 & 1157.061 & $<0.001$ \\
\hline Category & 85.560 & 2 & 42.780 & 1028.234 & $<0.001$ \\
\hline Distance & 15.109 & 3 & 5.036 & 121.054 & $<0.001$ \\
\hline Category * Distance & 25.449 & 6 & 4.241 & 101.946 & $<0.001$ \\
\hline Error & .915 & 22 & .042 & & \\
\hline Total & 194.422 & 34 & & & \\
\hline Corrected Total & 145.144 & 33 & & & \\
\hline
\end{tabular}

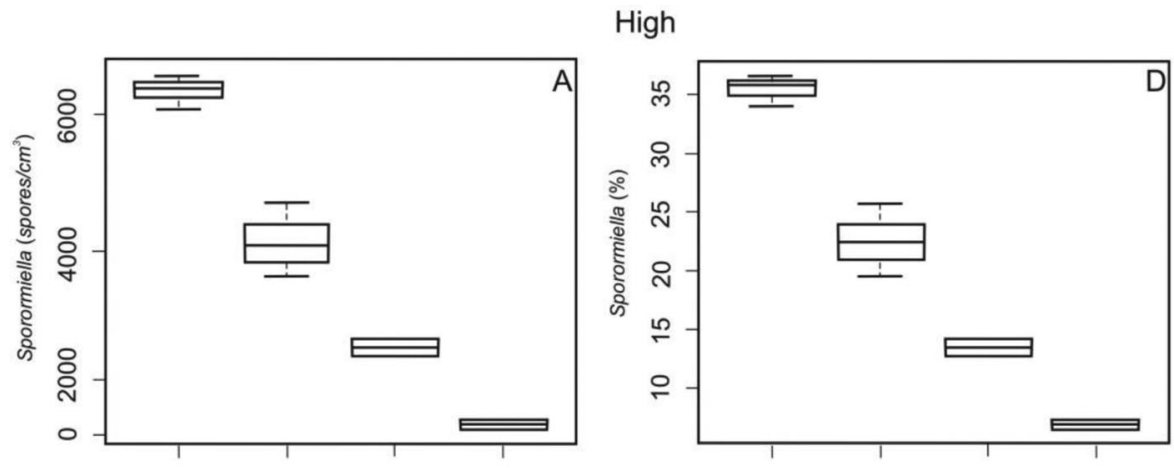

Medium
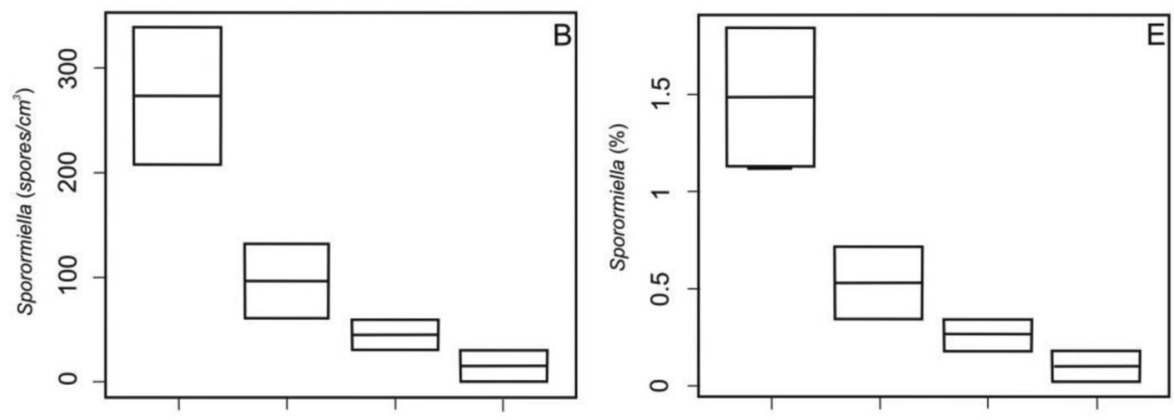

Low
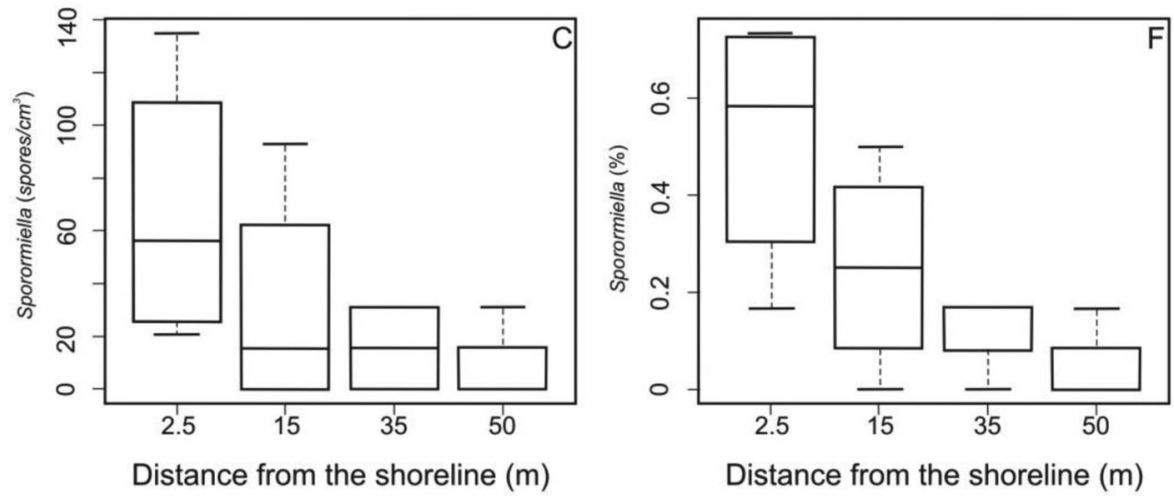

Figure 6. Generalized linear model for concentration (A-C) and percentage data (D-F) for all distances in each lake category.

Figura 6. Generalized linear model análise dos dados de concentração (A-C) e porcentagem (D-F) de todas as distancias para cada categoria de lago. 
Raczka, M.F. et al.

Table 4. Summary of the results for the generalized linear model on percentage data for all the distances for each lake category.

Tabela 4. Sumário dos resultados da análise linear dos dados de porcentagem para todas as distâncias para cada categoria de lago.

\begin{tabular}{|c|c|c|c|c|c|c|}
\hline & Distances & Estimate Std. & Error & t value & $\operatorname{Pr}(>|t|)$ & Signif. codes \\
\hline \multirow[t]{4}{*}{ High } & 2.5 & -0.59793 & $0.05793-$ & -10.322 & $4.83 \mathrm{e}-05$ & $* * *$ \\
\hline & 15 & -0.63843 & 0.08809 & 7.247 & -0.000351 & $* * *$ \\
\hline & 35 & -1.25848 & $0.11496-$ & -10.947 & $3.45 \mathrm{e}-05$ & $* * *$ \\
\hline & 50 & -2.00163 & $0.14578-$ & 13.730 & $9.28 \mathrm{e}-06$ & $* * *$ \\
\hline \multirow[t]{4}{*}{ Medium } & 2.5 & -4.1872 & $0.2159-$ & 19.393 & $4.17 \mathrm{e}-05$ & $* * *$ \\
\hline & 15 & -1.0565 & $0.4220-$ & 2.503 & 0.0665 & . \\
\hline & 35 & -1.8062 & 0.5686 & -3.176 & 0.0337 & $*$ \\
\hline & 50 & -2.9021 & 0.9334 & 3.109 & 0.0359 & $*$ \\
\hline \multirow[t]{5}{*}{ Low } & 2.5 & 0.0627 & 0.4395 & 0.143 & 0.8889 & + \\
\hline & 15 & -1.1621 & 0.6712 & -1.731 & 0.1090 & + \\
\hline & 35 & -2.0111 & 0.7969 & -2.524 & 0.0267 & $*$ \\
\hline & $\mathbf{5 0}$ & -3.1982 & 1.1837 & -2.702 & 0.0192 & * \\
\hline & Signif. codes: & $\mathbf{0} * * * *$ & $0.001^{\prime} * *$ ' & 0.01 '*' & $0.05^{\prime} ?$ & $0.1^{\prime}+{ }^{\prime}$ \\
\hline
\end{tabular}

than $1.8 \%$ (338.73 spores per $\mathrm{cm}^{3}$ of sediment) of the total pollen sum. Although all categories exhibited the same tendency for Sporormiella abundance to decline toward the center of the lake, the variance between samples was markedly lower at locations with medium and low cattle use, especially for samples at 15, 35, and $50 \mathrm{~m}$ from the shoreline (Figures $6 \mathrm{~B}, \mathrm{E}, \mathrm{C}$ and F).

\section{Discussion}

Based on modern samples collected in areas with high, medium, and low cattle use our results validate Sporormiella as a robust instrument to predict past grazing activities in ancient lake records, as suggested by (Davis 1987), and later observed by other researches (Burney et al. 2003, Davis \& Shafer 2006, Gill et al. 2009, Robinson et al. 2005). In essence, large numbers of livestock resulted in more spores of Sporormiella being deposited to the center of a lake than low densities of livestock.

The presence of small- and medium-sized herbivores, other than domesticated livestock, appeared to have very little influence on the abundance of Sporormiella spores. As these small animals probably support Sporormiella, its representation may not decline to zero even following a megafaunal extinction event. Our results are consistent with the $2 \%$ detection threshold suggested by Davis (1987), in which Sporormiella occurrence at $>2 \%$ of the pollen sum was a reliable indicator of megafaunal presence. This $2 \%$ value has been used to indicate the possible functional extinction of megafauna from the catchment area of the lake (Gill et al. 2013, Gill et al. 2009, Johnson et al. 2015, Parker \& Williams 2012). This threshold, however, will probably vary depending on the location of the study as the percentage of Sporormiella is dependent on the pollen productivity of the system. Equally important are the concentrations values, which compare positively with the spore percentage data. All samples from locations with high cattle use had Sporormiella values greater than $2 \%$, even from samples located at the center of the lake. On the other hand, at locations with medium and low cattle use, which could be a parallel for a functional extinction in the past, the highest value of the highest average of Sporormiella was $1.8 \%$ of the total pollen sum. The values for locations with high cattle use are, without exception, greater than any samples at medium and low cattle use locations (Figure 6). This finding has important implications for paleoecological studies because it suggests that

Table 5. Summary of the results for the generalized linear model on concentration data for all the distances for each lake category.

Tabela 5. Sumário dos resultados da análise linear dos dados de concentração para todas as distâncias para cada categoria de lago.

\begin{tabular}{|c|c|c|c|c|c|c|}
\hline & Distances & Estimate Std. & Error & $t$ value & $\operatorname{Pr}(>|t|)$ & Signif. codes \\
\hline \multirow[t]{4}{*}{ High } & 2.5 & -5.02812 & 0.04217 & -119.230 & $2.35 \mathrm{e}-11$ & $* * *$ \\
\hline & 15 & -0.45213 & 0.06753 & -6.695 & 0.000539 & $* * *$ \\
\hline & 35 & -0.96383 & 0.09336 & -10.324 & $4.83 \mathrm{e}-05$ & $* * *$ \\
\hline & 50 & -1.62970 & 0.12348 & -13.198 & $1.17 \mathrm{e}-05$ & $* * *$ \\
\hline \multirow[t]{4}{*}{ Medium } & 2.5 & -0.9780 & 0.2670 & -3.662 & 0.0215 & $*$ \\
\hline & 15 & -1.2564 & 0.4831 & -2.600 & 0.0600 & . \\
\hline & 35 & -2.0741 & 0.6324 & -3.280 & 0.0305 & $*$ \\
\hline & 50 & -3.1944 & 1.0092 & -3.165 & 0.0340 & $*$ \\
\hline \multirow[t]{5}{*}{ Low } & 2.5 & -2.6338 & 0.4004 & -6.577 & $2.62 \mathrm{e}-05$ & $* * *$ \\
\hline & 15 & -0.8123 & 0.7037 & -1.154 & 0.2708 & + \\
\hline & 35 & -1.5196 & 0.9047 & -1.680 & 0.1189 & + \\
\hline & 50 & -2.2227 & 1.2120 & -1.834 & 0.0916 & . \\
\hline & Signif. codes: & $0 * * * *$ & 0.001 '**' & 0.01 '* & $0.05^{\prime} ?$ & $0.1^{6}+$ \\
\hline
\end{tabular}


the presence of megafauna can be detected even without knowing the exact locations of paleo-shorelines.

Distance from the shoreline played an important role in the number of spores recovered. It was previously suggested that due to their density, and the clumping of spores as they are released, Sporormiella would have had a limited dispersal range (Parker \& Williams 2012). Consequently, spores of Sporormiella would be expected to be concentrated at the margins of lakes. Our results, along with those of Raper \& Bush (2009), support this observation. Similarly, our data are consistent with most other studies in that they show Sporormiella spore concentrations and percentages of the pollen sum declining toward the center of the lake.

Raper \& Bush (2009) noticed a weak relationship between the percentages of Sporormiella and distance from the shoreline at Corner Lake, a location with high cattle activity. This observation could be an artifact of the sampling method applied by those authors, who used a linear transect as a representation of the entire shoreline. To prevent this, the collection of modern samples in our study differed from the method applied by Raper \& Bush (2009). We randomly selected samples around the lake to avoid collecting samples closer to a source of Sporormiella, or to accidentally select any spot that cattle were avoiding.

Sample location and livestock use are two factors to consider when analyzing the percentages and concentrations of Sporormiella in modern settings at any location. Similarly, the morphology of the basin should also be properly evaluated. Etienne et al. (2012) observed that Sporormiella abundance at Lake Allos is strongly related to stream flooding, and the authors suggest that a single core obtained at the center of a lake could be a misrepresentation of megafaunal presence in fossil records. Etienne et al. (2012), however, performed their analysis very close to the course of a stream, thereby, emphasizing the role that moving water could play an important part in dispersing Sporormiella into a lake, Their study underlines the care needed in selecting a site for any kind of paleoecological reconstruction, as the biases they found in Sporormiella distribution would apply equally to other proxies.

One pair of lakes in our study provided some further insights into the importance of stream flow on Sporormiella inputs. Lake Pedrinha, a site with high cattle use, had a small inflowing stream that during the wet season would have the capacity to produce flood surges. We chose a coring location, as we would for any paleoecological reconstruction that was not aligned with the stream and its alluvial fan. A comparison of the Sporormiella concentrations observed in sediments from this lake was not significantly different to those documented from Lake Araça, which is also a high cattle use location, but lacking a stream input. As Sporormiella spores settle out quite quickly, representative samples can be collected by avoiding areas of stream activity.

\section{Conclusion}

Our results from 9 lakes and a total of 120 samples indicated that spores of Sporormiella are a very sensitive proxy for large herbivore presence. Sporormiella is an important paleoecological proxy measure for identifying the presence, and with appropriate metadata, the abundance of megaherbivores. The abundance and concentration of Sporormiella spores can be used to assess the timing of the functional extinction of the late-Pleistocene megafauna in the Neotropics.

Distance from the source of dispersion plays an important role in the abundance of spores recovered. As the distance towards the center of the lake increases, the number of spores decreases considerably. Therefore, the location of the core relative to paleoshorelines is important for fossil reconstructions. To overcome this issue multiple cores taken across a basin, cores close to the shoreline of a lake or using independent proxies for lake depth such as fossil diatom abundances coupled with bathymetric models could be used to refine analyses.

As previously stated by some authors (Baker et al. 2013, Johnson et al. 2015), the study of representation of the coprophilous genus Sporormiella offers an immense opportunity for a complete approach to understand the past environment: ecosystem and biodiversity of megafauna. Extinctions are extremely complicated processes and are seldom caused by a single, distinct event. In most cases, extinctions are a consequence of a major event that culminates in cascading effects that disturb entire systems (Raup 1991, 1994). We may never identify a single cause for the loss of the Pleistocene megafauna, however, we should make use, as much as we can, of any tool available to understand it; analysis of Sporormiella is certainly one of those tools.

\section{Acknowledgments}

This research was funded by National Science Foundation (NSF) award DEB 1260983. We thank Instituto Estadual de Florestas (IEF/MG), and Gerência de Projetos e Pesquisas (GPROP) for the authorization (UC 044/13) to collect samples at Lagoa do Sumidouro. We also thank Paulo Eduardo De Oliveira and Rudney Almeida for the field assistance. We also thank Pablo Juarbe Martinez for helping with the pictures.

\section{References}

ABSY, M.L. 1991. Occurrence of four episodes of rain forest regression in southeastern Amazonia during the last 60000 yrs. First comparison with other tropical regions. Comptes Rendus - Academie des Sciences, Serie II. 312. 6:673-678

APTROOT, A. \& VAN GEEL, B. 2006. Fungi of the colon of the Yukagir Mammoth and from stratigraphically related permafrost samples. Review of Palaeobotany and Palynology. 141. 1-2:225-230, http://dx.doi.org/10.1016/j.revpalbo.2005.04.006

AUGUSTINE, D.J. \& MCNAUGHTON, S.J. 1998. Ungulate Effects on the Functional Species Composition of Plant Communities: Herbivore Selectivity and Plant Tolerance. The Journal of Wildlife Management. 62. 4:1165-1183, http://dx.doi.org/10.2307/3801981.

BAKER, A.G., BHAGWAT, S.A. \& WILLIS, K.J. 2013. Do dung fungal spores make a good proxy for past distribution of large herbivores? Quaternary Science Reviews. 62.21-31.

BAKKER, E.S., GILL, J.L., JOHNSON, C.N., VERA, F.W.M., SANDOM, C.J., ASNER, G.P. \& SVENNING, J.-C. 2015. Combining paleo-data and modern exclosure experiments to assess the impact of megafauna extinctions on woody vegetation. Proceedings of the National Academy of Sciences, http://dx.doi.org/ 10.1073/pnas.1502545112.

BARNOSKY, A.D. \& LINDSEY, E.L. 2010. Timing of Quaternary megafaunal extinction in South America in relation to human arrival and climate change. Quaternary International. 217. 1-2:10-29, http://dx.doi.org/10.1016/j.quaint.2009.11.017.

BORRERO, L.A. 2009. The elusive evidence: The archaeological record of the South America extinct megafauna. Book. The elusive 
evidence: The archaeological record of the South America extinct megafauna(G. Haynes). Springer, USA, 145-168, http://dx.doi.org/ 10.1007/978-1-4020-8793-6_8.

BURNEY, D.A., ROBINSON, G.S. \& BURNEY, L.P. 2003. Sporormiella and the late Holocene extinctions in Madagascar. Proceedings of the National Academy of Sciences of the United States of America. 100. 19:10800-10805, http://dx.doi.org/10.1073/pnas.1534700100.

COLINVAUX, P.A., BUSH, M.B., STEINITZ-KANNAN, M. \& MILLER, M.C. 1997. Glacial and Postglacial Pollen Records from the Ecuadorian Andes and Amazon. Quaternary Research. 48. 1:69-78, http://dx.doi.org/10.1006/qres.1997.1908.

COLINVAUX, P.A., DE OLIVEIRA, P.E. \& MORENO, J.E. 1999. Amazon pollen manual and atlas. Gordon and Breach (Harwood), London/New York, http://dx.doi.org/10.1002/jqs.2597.

COLINVAUX, P.A., DE OLIVEIRA, P.E., MORENO, J.E., MILLER, M.C. \& BUSH, M.B. 1996. A Long Pollen Record from Lowland Amazonia: Forest and Cooling in Glacial Times. Science. 274. 5284:85-88.

DAVIS, O.K. 1987. Spores of the Dung Fungus Sporormiella Increased Abundance in Historic Sediments and before Pleistocene Megafaunal Extinction. 294. 290-294, http://dx.doi.org/10.1016/0033-5894(87) 90067-6.

DAVIS, O.K., KOLVA, D.A. \& MEHRINGER, P.J. 1977. Pollen analysis of Wildcat Lake, Whitman County, Washington: the last 1000 years. Northwest. Sci. 51. 13-30.

DAVIS, O.K. \& SHAFER, D.S. 2006. Sporormiella fungal spores, a palynological means of detecting herbivore density. Palaeogeography, Palaeoclimatology, Palaeoecology. 237. 1:40-50, http://dx. doi.org/10.1016/j.palaeo.2005.11.028.

DOUGHTY, C.E., WOLF, A. \& MALHI, Y. 2013. The legacy of the Pleistocene megafauna extinctions on nutrient availability in Amazonia. Nature Geoscience. 6. 9:761-764, http://dx.doi.org/10.1038/ ngeo1895.

ETIENNE, D., WILHELM, B., SABATIER, P., REYSS, J.-L. \& ARNAUD, F. 2012. Influence of sample location and livestock numbers on Sporormiella concentrations and accumulation rates in surface sediments of Lake Allos, French Alps. Journal of Paleolimnology. 49. 2:117-127, http://dx.doi.org/10.1007/s10933-012-9646-x.

FAEGRI, K. \& IVERSEN, J. 1989. A textbook of pollen analysis. Fourth edi. John Wiley \& Sons, New York.

FROYD, C.A., COFFEY, E.E.D., VAN DER KNAAP, W.O., VAN LEEUWEN, J.F.N., TYE, A. \& WILLIS, K.J. 2013. The ecological consequences of megafaunal loss: giant tortoises and wetland biodiversity. Ecology Letters. n/a--n/a, http://dx.doi.org/10.1111/ele.12203.

GELMAN, A. \& HILL, J. 2007. Data analysis using regression and multilevel/hierarchical models. Cambridge University Press,

GILL, J.L. 2014. Ecological impacts of the late Quaternary megaherbivore extinctions. New Phytologist. 201. 4:1163-1169, http:// dx.doi.org/10.1111/nph.12576.

GILL, J.L., MCLAUCHLAN, K.K., SKIBBE, A.M., GORING, S., ZIRBEL, C.R. \& WILLIAMS, J.W. 2013. Linking abundances of the dung fungus Sporormiella to the density of bison: implications for assessing grazing by megaherbivores in palaeorecords. Journal of Ecology. 101. 5:1125-1136, http://dx.doi.org/10.1111/1365-2745. 12130.

GILL, J.L., WILLIAMS, J.W., JACKSON, S.T., DONNELLY, J.P. \& SCHELLINGER, G.C. 2012. Climatic and megaherbivory controls on late-glacial vegetation dynamics: a new, high-resolution, multiproxy record from Silver Lake, Ohio. Quaternary Science Reviews. 34.66-80, http://dx.doi.org/10.1016/j.quascirev.2011.12.008.

GILL, J.L., WILLIAMS, J.W., JACKSON, S.T., LININGER, K.B. \& ROBINSON, G.S. 2009. Pleistocene megafaunal collapse, novel plant communities, and enhanced fire regimes in North America. Science. 326. 5956:1100-1103, http://dx.doi.org/10.1126/science.1179504.

GOODLAND, R. \& POLLARD, R. 1973. The Brazilian Cerrado Vegetation: A Fertility Gradient. Journal of Ecology. 61. 1:219-224, http://dx.doi.org/10.2307/2258929.
GRAYSON, D.K. \& MELTZER, D.J. 2002. Clovis Hunting and Large Mammal Extinction : A Critical Review of the Evidence. 16. 4, http:// dx.doi.org/10.1023/A:1022912030020.

JOHNSON, C.N. 2002. Determinants of loss of mammal species during the Late Quaternary 'megafauna' extinctions: life history and ecology, but not body size. Proceedings. Biological sciences / The Royal Society. 269. 1506:2221-2227, http://dx.doi.org/10.1098/ rspb.2002.2130.

JOHNSON, C.N. 2009. Ecological consequences of Late Quaternary extinctions of megafauna. Proceedings. Biological sciences / The Royal Society. 276. 1667:2509-2519, http://dx.doi.org/10.1098/ rspb.2008.1921.

JOHNSON, C.N., RULE, S., HABERLE, S.G., TURNEY, C.S.M., KERSHAW, A.P. \& BROOK, B.W. 2015. Using dung fungi to interpret decline and extinction of megaherbivores: problems and solutions. Quaternary Science Reviews. 110. 0:107-113, http://dx. doi.org/10.1016/j.quascirev.2014.12.011.

LEDRU, M.-P., SALGADO-LABOURIAU, L. \& LORSCHEITTER, L. 1998. Vegetation dynamics in southern and central Brazil during the last 10, 000 yr B. P., http://dx.doi.org/10.1016/S0034-6667(97) 00049-3.

LEDRU, M.L. 1993. Late Quaternary environmental and climatic changes in central Brazil. Quaternary Research. 39. 90-98, http:// dx.doi.org/10.1006/qres.1993.1011.

MACFADDEN, B.J. \& SHOCKEY, B.J. 1997. Ancient Feeding Ecology and Niche Differentiation of Pleistocene Mammalian Herbivores from Tarija, Bolivia: Morphological and Isotopic Evidence. Paleobiology. 23. 1:77-100, http://dx.doi.org/10.1017/S0094 837300016651.

MACPHEE, R.D.E. 1999. Extinctions in near time: Causes, contexts and consequences. Kluwer/Plenum, New York.

MARTIN, P.S. 1973. The Discovery of America. Science. 179. 969-974.

MARTIN, P.S. \& KLEIN, R.G. 1984. Quaternary extinctions: A prehistoric revolution. University of Arizona Press, Tucson.

MARTIN, P.S. \& STEADMAN, D.W. 1999. Prehistoric extinction on islands and continents. Book. Prehistoric extinction on islands and continents (R. D. E. MacPhee and H.-D. Sues). Springer, 17-56, http://dx.doi.org/10.1007/978-1-4757-5202-1_2.

MCNAUGHTON, S.J. 1985. Ecology of a Grazing Ecosystem: The Serengeti. Ecological Monographs. 55. 3:259-294, http://dx.doi. org/10.2307/1942578.

MILlER, G.H., MAGEE, J.W., JOHNSON, B.J., FOGEL, M.L., SPOONER, N.A., MCCULLOCH, M.T. \& AYLIFFE, L.K. 1999. Pleistocene Extinction of Genyornis newtoni: Human Impact on Australian Megafauna. Science. 283. 5399:205-208, http://dx.doi. org/10.1126/science.283.5399.205.

MORELLATO, L.P.C. \& HADDAD, C.F.B. 2000. Introduction: The Brazilian Atlantic Forest1. Biotropica. 32. 4b:786-792, http://dx. doi.org/10.1111/j.1744-7429.2000.tb00618.x.

PARKER, N.E. \& WILLIAMS, J.W. 2012. Influences of climate, cattle density, and lake morphology on Sporormiella abundances in modern lake sediments in the US Great Plains. Holocene. 22. 4:475-483, http://dx.doi.org/10.1177/0959683611425550.

RAPER, D. \& BUSH, M. 2009. A test of Sporormiella representation as a predictor of megaherbivore presence and abundance. Quaternary Research. 71. 3:490-496, http://dx.doi.org/10.1016/j.yqres.2009.01.010.

RAUP, D.M. 1991. Extinction. Bad Genes or Bad Luck? Norton, http://dx.doi.org/10.1046/j.1420-9101.1993.6030459.x.

RAUP, D.M. 1994. The role of extinction in evolution. Proceedings of the National Academy of Sciences. 91. 15:6758-6763

RIPPLE, W.J. \& VAN VALKENBURGH, B. 2010. Linking Top-down Forces to the Pleistocene Megafaunal Extinctions. BioScience. 60. 7: 516-526, http://dx.doi.org/10.1525/bio.2010.60.7.7.

ROBINSON, G.S., PIGOTT BBURNEY, L. \& BURNEY, D.A. 2005. Landscape paleoecology and megafaunal extinction in southeastern New York State. Ecological Monographs. 75. 3:295-315, http://dx.doi.org/10.1890/03-4064. 
SMITH, F.A., ELLIOTT, S.M. \& LYONS, S.K. 2010. Methane emissions from extinct megafauna. Nature Geosci. 3. 6:374-375, http://dx.doi.org/10.1038/ngeo877.

STOCKMARR, J. 1971. Tablets with spores used in absolute pollen analysis. Pollen et Spores. v. 13.615-621.

VAN GEEL, B., GUTHRIE, R.D., ALTMANN, J.G., BROEKENS, P., BULL, I.D., GILL, F.L., JANSEN, B., NIEMAN, A.M. \& GRAVENDEEL, B. 2011. Mycological evidence of coprophagy from the feces of an Alaskan Late Glacial mammoth. Quaternary
Science Reviews. 30. 17-18:2289-2303, http://dx.doi.org/10.1016/j. quascirev.2010.03.008.

WEBB, S.D., MILANICH, J.T., ALEXON, R. \& DUNBAR, J.S. 1984. A Bison Antiquus kill site, Wacissa River, Jefferson County, Florida. American Antiquity. 49. 2:384-392.

WOOD, J.R., WILMSHURST, J.M., WORTHY, T.H. \& COOPER, A. 2011. Sporormiella as a proxy for non-mammalian herbivores in island ecosystems. Quaternary Science Reviews. 30. 7-8:915-920, http://dx.doi.org/10.1016/j.quascirev.2011.01.007. 